JFDS-2016-2027.R1

\title{
Increasing oil concentration affects consumer perception and physical properties of mayonnaise-type spreads \\ containing $\mathrm{KCl}$
}

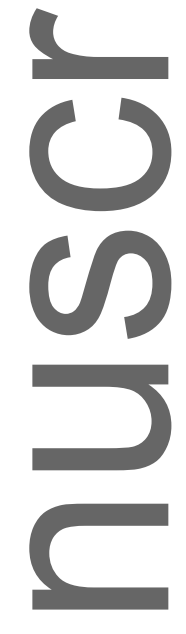

Damir Dennis Torrico ${ }^{1,2^{*}}$ and Witoon Prinyawiwatkul ${ }^{2}$

${ }^{1}$ Faculty of Veterinary and Agricultural Sciences, The University of Melbourne, Parkville, VIC 3010, Australia

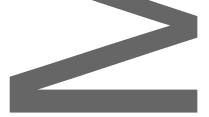

${ }^{2}$ School of Nutrition and Food Sciences, Louisiana State University Agricultural Center, Baton Rouge,

LA 70803-4200, USA

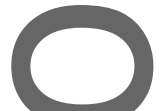

Running Title: Oil concentration affects taste...

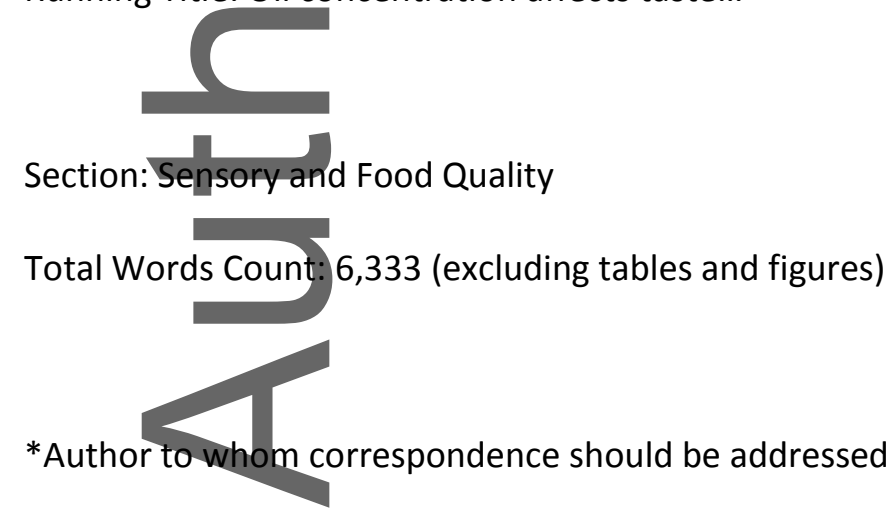

This is the author manuscript accepted for publication and has undergone full peer review but has not been through the copyediting, typesetting, pagination and proofreading process, which may lead to differences between this version and the Version of Record. Please cite this article as doi: 10.1111/1750-3841.13781.

This article is protected by copyright. All rights reserved. 
Tel +61383449698

E-mail: damir.torrico@unimelb.edu.au

\section{Abstract}

\section{r}

Reducing sodium intakes remains a global challenge for the food industry. $\mathrm{KCl}$ is a potential salt substitute but imparts bitterness when used at high concentrations. Little is known about how oil concentrations $(\mathrm{OC})$ affect consumers' perception of saltiness and bitterness in emulsion products such as mayennaise containing $\mathrm{KCl}$. We evaluated consumers' perception and physical properties of mayonnaise-type spreads at various oil and tastant $(\mathrm{NaCl}$ or $\mathrm{KCl})$ concentrations. Consumers $(\mathrm{N}=306)$ evaluated saltiness, bitterness, overall taste liking (OTL) and purchase intent (PI). Viscosity, pH, water activity and consistency/texture were also measured. Oil and tastant $(\mathrm{NaCl}$ or $\mathrm{KCl}$ ) concentrations had significant effects on saltiness, viscosity, and $\mathrm{pH}$. As OC increased, saltiness intensity slightly decreased for spreads. Increasing oil concentration increased viscosity. Generally, spreads containing $\mathrm{KCl}$ had higher bitterness and $\mathrm{pH}$ than spreads containing $\mathrm{NaCl}$. All spreads containing $\mathrm{KCl}$ were penalized for being "too bitter". PI was affected by OTL for all spreads but OC was also a significant factor in the purchase decision of spreads containing $\mathrm{NaCl}$. This study demonstrated that increasing OC affected consumers' taste perception (saltiness and bitterness) and spreads' physical properties including $\mathrm{pH}$ and viscosity.
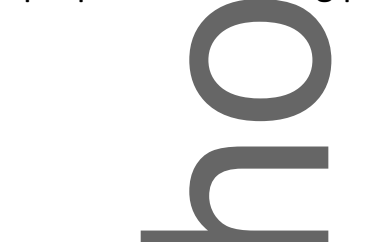

Keywords: saltiness; bitterness; $\mathrm{NaCl}$; KCl; oil-in-water emulsion.

\section{Practical applications:}

The strong association between excessive sodium consumption and hypertension and cardiovascular diseases is pressuring the food industry to find alternatives to replace sodium in foods. $\mathrm{KCl}$, a salt substitute, may impart bitterness and metallic aftertaste. The composition of food matrices plays an 
important role in consumer acceptability. This study evaluated consumer perception and physical properties of mayonnaise-type spreads at various oil and tastant $(\mathrm{NaCl}$ or $\mathrm{KCl})$ concentrations. Increasing oil and tastant concentrations significantly affects perception and acceptability of spreads. This study can help the food industry to understand effects of oil concentrations on sensory properties of reduced-sodium emulsion products.

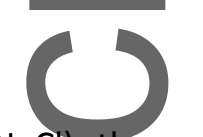

\section{Introduction}

Salt $(\mathrm{NaCl})$, the most common food additive in the food industry, is used to provide salty taste and to improve flayor in foods. It is also used for food preservation, structuring and other important food applications (Kilcast and den Ridder 2007; Heshmati 2014). However, elevated sodium intake is associated with hypertension and cardiovascular diseases, which are the leading causes of deaths in the United States (Appel and others 2011; CDC 2016). Several approaches have been investigated to reduce sodium in human diets including stealth sodium reductions, saltiness potentiation, multisensory applications, and physical modifications of salt crystals (Kuo and Lee 2014). Use of salt substitutes (ingredients that taste salty but with no sodium) is an alternative for sodium reduction (Liem and others 2011) but it appears no other salt can match $\mathrm{NaCl}$ in terms of taste quality and acceptability. Saltiness of $\mathrm{NaCl}$ is unique, pure and clean as its cation and anion are associated with overall taste quality (Murphy and others 1981; Deman 1976). Potassium chloride (KCl) is a potential salt substitute; however, $\mathrm{KCl}$ has the drawback of imparting bitterness, metallic aftertaste, and offtaste (Hooge and Chambers 2010).

Modifying food matrix properties that affect sodium release and saltiness perception is another approach for reducing sodium (Kuo and Lee 2014; Busch and others 2013; Thurgood and Martini 2010). This includes the modification of viscosity, overall salt distribution, and $\mathrm{pH}$ (Busch and others 2013). Previous studies by our research group demonstrated that modifying physical properties of oil-in-water emulsions containing $\mathrm{KCl}$ significantly affected taste perception (Torrico and others 2015a; Torrico and others 2015b, Torrico and others 2015c). These studies concluded that oil in 
emulsion systems exhibited a bitterness-suppressing effect at recognition threshold levels $\quad<0.12$ $\mathrm{g} / 100 \mathrm{ml}$ of $\mathrm{KCl}$; Torrico and others $2015 \mathrm{c}$ ), and a saltiness-enhancing effect at consumer consumption levels ( $0.5 \%$ to $1.5 \%$ of $\mathrm{KCl}$; Torrico and others $2015 \mathrm{a}$ ). However, food matrices are complex systems with several binary and tertiary interactions among basic tastes. In food-emulsion models, Shamil and others (1991-1992) stated that fat increased saltiness in salad creams, and decreased bitterness in Cheddar cheeses. Wendin and others (1999) reported that decreasing oil content in mayonnaise decreased sourness due to a water dilution effect of acetic acid. In a different study, Wendin and others (2000) demonstrated that increasing fat content enhanced saltiness of cream cheeses. Koriyama and others (2002) found that oil did not affect sweetness nor saltiness directly but decreased sourness and bitterness in emulsions. In terms of acceptability, Lin and others (1991) demonstrated that partial substitution of $\mathrm{NaCl}$ with $\mathrm{KCl}(18.3 \%)$ provided optimal sensory responses in restructured hams. $\mathrm{KCl}$ partial replacement of sodium produced significant increases in bitterness but did not affect flavor of bologna (Seman and others 1980). The acceptability level of $\mathrm{KCl}$ replacements or substitutions is dependent on the composition of the food matrix system (Hooge and Chambers 2010).

There are few studies attempting to understand the effects of oil on taste perception in food emulsion systems containing $\mathrm{KCl}$. Thus, the objective of this research was to evaluate consumer perception and physical properties of mayonnaise-type spreads at various oil and tastant concentrations to unveil main sensory and physical differences of $\mathrm{NaCl}$ and $\mathrm{KCl}$ in oil-in-water emulsion systems

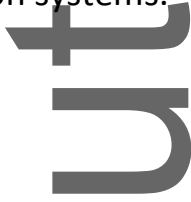

\section{Preparation of mayonnaise-type spreads}

\section{Materials and Methods}

Mayonnaise-type spreads were similarly prepared to the procedure described in Garcia and others (2009). Canola oil (CWP, Cal Western Packaging Corp., Memphis, Tenn., U.S.A.) and Ozarka ${ }^{\circledR}$ 
spring water (Nestle Waters North America, Greenwich, Conn., U.S.A.) were used as the base formulation for all emulsions. Tic Pretested ${ }^{\circledR}$ Ticaloid $^{\circledR} 210$ S powder (gum acacia and xanthan gum; Tic Gums ${ }^{\circledR}$,Inc., White Marsh, Md., U.S.A.) was used as a stabilizer, whey protein isolate (Grande Ultra ${ }^{\circledR}$, Grande Custom Ingredients Group, Lomira, Wis., U.S.A.) was used as gelation and thickening agent, vinegar (Great Value ${ }^{\mathrm{TM}}$, Walmart, Ark., U.S.A.) was used as an acidifier, and sodium chloride ( $\mathrm{NaCl}$, Morton Intl., Inc., Chicago, III, U.S.A.) or potassium chloride ( $\mathrm{KCl}, 99 \% \mathrm{FCC}$ grade, Extracts and Ingredients, Ltd., Union, N.J., U.S.A.) were used as main tastants. For preparing the spreads, ingredients were first weighed out using an analytical balance (MS105, Mettler-Toledo, L.C.C., Columbus, Ohio, U.S.A.) according to the formulations described in Table 1. $\mathrm{NaCl}$ or $\mathrm{KCl}$, Tic gum, whey protein isolate and vinegar were thoroughly dissolved in water and mixed with canola oil for 15 min using a hand-held blender at high-speed (Model \#59780R, Hamilton Beach ${ }^{\circledR}$ Brands Canada, Inc., Picton, Ont., Canada). After forming the emulsion, each spread sample was poured into $500 \mathrm{~mL}$ plastic containers and kept at refrigerated temperature $\left(4^{\circ} \mathrm{C}\right)$ prior to testing. Before serving, $30 \mathrm{~mL}$ of spread sample was poured into a plastic cup with a lid that was previously coded with 3-digit random numbers. Differences in concentrations of $\mathrm{NaCl}$ and $\mathrm{KCl}$ (Table 1) for the experimental design were pre-determined according to their relative saltiness intensities described in Torrico and others (2015b).

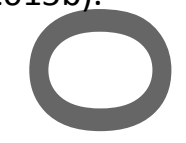

\section{Physical properties of mayonnaise-type spreads}

Viscosity of each spread sample was measured in centipoise $(\mathrm{CP})$ at $20 \pm 0.5^{\circ} \mathrm{C}$ using a viscometer (model DV-Ill, Brookfield Engineering Labs Inc., Middleboro, Mass., U.S.A.) at $1 \mathrm{rpm}$ and a RV-IV spindle with data gathered in the Wingather V2.1 software (Brookfield Engineering Labs Inc.). For viscosity measurements, $65 \%$ oil spreads were excluded from the study since their viscosity values exceeded the allowed upper limit viscosity of the instrument (99999 cP). The pH of each spread sample was measured using an Orion 520 pH meter (Orion Labs, Tucson, Ariz., U.S.A). The water 
activity $\left(a_{w}\right)$ of each spread sample was measured using a water activity meter (HygroLab 3, Rotronic A.G, Bassersdorf, Switzerland). Triplicate measurements from two independent batches of each spread treatment were assessed for all physical properties.

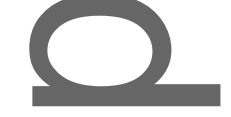

\section{Textural properties of mayonnaise-type spreads}

For texture analysis, a $25 \mathrm{~mL}$ spread sample was poured into a $50 \mathrm{~mL}$ beaker and a compression test was applied to the liquid emulsion using an automatic texture analyzer TA-XT2 PLUS (Stable Micro Systems, Godalming, U. K.; Exponent 32 V 1.0.0.13 software) fitted with a 1/2 inch stainless steel ball probe (TA-18). Cohesiveness, springiness, gumminess, resilience and adhesiveness were calculated as described by Bourne (1978). For texture analysis, two independent samples were selected randomly from each of the 18 spread formulations (Table 1).

\section{Consumer evaluation of mayonnaise-type spreads}

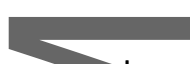

The research protocol for this study was approved (IRB\# HE 15 to 9) by the Louisiana State Univ. Agricultural Center Institutional Review Board. The consumer evaluation was conducted in the Sensory Analysis Laboratory, School of Nutrition and Food Sciences, Louisiana State Univ. Agricultural Center, Baton Rouge, La., U.S.A. The testing room was illuminated with cool, natural, LED lights and evaluations were conducted in individual booths located in the sensory laboratory. Panelists from a pool of faculty, staff, and students at Louisiana State Univ. were recruited and prescreened using the following criteria: 1. regular consumers of mayonnaise products based on (1) self-reported responses and 2. not having taste/smell disorders and/or kidney/liver problems. Consumers ( $N=306$; $65 \%$ females, $35 \%$ males) were briefed about the questions, particularly, the sensory attributes and their meanings, and sample handling during the evaluation. A plastic spoon to taste the sample, and crackers, water, and expectoration cups to minimize any residual effects between samples were provided to consumers during the test. A Balanced Incomplete Block (BIB) 
Design [ $\mathrm{t}=18, \mathrm{k}=3, \mathrm{r}=17, \mathrm{~b}=102, \lambda=2, \mathrm{E}=0.71$; generated by PROC OPTEX (SAS Int. 2012)] was used. Each consumer tasted only 3 samples (out of 18). The BIB design was repeated 3 times resulting in a total of 51 observations per mayonnaise-type spread treatment (Table 1). The Compusense five (Compusense Inc., Guelph, Canada) computerized data collection system was used for questionnaire development and data collection.

In the sensory session, consumers were asked to rate saltiness and bitterness of the emulsion (spread) samples using a 100-point labelled magnitude scale (LMS; Green and others 1993). Sensory properties of the spreads were assessed including saltiness, bitterness and thickness/viscosity using a 5-point just about right scale (JAR; 1 = much too weak, 3 = just about right, 5 = much too strong), and overall taste-liking using a 9-point hedonic scale $(1=$ dislike extremely, $5=$ neither dislike nor like, 9 = like extremely) (Peryam and Pilgrim 1957). Purchase intent of each spread sample was determined using a binomial (yes/no) scale (Sae-Eaw and others 2007).

\section{Experimental design and statistical analyses}

Following the BIB design, a full factorial treatment arrangement $(2 \times 3 \times 3)$ was used to investigate the effects of three factors $[2$ tastant types $(\mathrm{NaCl}$ or $\mathrm{KCl}) \times 3$ tastant concentrations $(0.5,0.75$ and $1.0 \%$ for $\mathrm{NaCl}$ or $0.5,1.0$ and $1.5 \%$ for $\mathrm{KCl}) \times 3$ oil concentrations $(45,55$ and $65 \%)]$ (Table 1$)$ on physical, textural and sensory properties of the spread samples. Univariate and regression data were analyzed at $\alpha=0.05$ using the SAS software 9.1.3 (SAS Inst. 2012). Multivariate data were analyzed using a customized code written in Matlab (Matworks Inc., Matick, Mass., U.S.A.) which allowed finding patterns within data and samples (Fuentes, unpublished). Analysis of Variance (ANOVA) and the post-hoc Tukey's studentized range test were used to locate significant differences among samples. Consumers data from LMS responses were fitted using the response surface methodology (RSM) with a second-order polynomial $\hat{Y}=b_{0}+b_{1} X_{1}+b_{2} X_{2}+b_{11} X_{1}^{2}+b_{22} X_{2}^{2}+b_{12} X_{1} X_{2}$ model where $\hat{Y}$ was the predicted response (saltiness or bitterness intensity); $b_{0}$ was the value of the fitted 
response at the center point of the design; $b_{1}$ and $b_{2}$ were linear regression terms; $b_{11}$ and $b_{22}$ were quadratic regression terms; and $b_{12}$ was the cross product regression term. For JAR and overall taste liking scores, a penalty analysis was performed to measure the negative effect of each sensory attribute (saltiness, bitterness or viscosity) on overall taste liking. Total penalty scores (TPS) were computing by multiplying mean drops [differences between overall taste liking scores rated at "not$J A R^{\prime \prime}$ (either too weak or too strong) minus liking scores at JAR] by frequency percentages of consumers at each "not-JAR" category (Walker 2016). Multivariate Analysis of Variance (MANOVA) was used to defermine whether significant differences existed among spread samples when intercorrelations among all physical, textural and sensory attributes were tested, simultaneously. For the MANOVA, the single linkage hierarchical clustering algorithm based on Euclidean distances was used to identify clusters of spread samples based on all attributes. Subsequently, principal component analysis (PCA) was performed to demonstrate correlations among the physical/textural/sensory qualities and spread samples as illustrated in the product-attribute bi-plot (Lipkovich and Smith 2001). Logistic regression analysis was performed to predict the positive purchase intent of mayonnaise-type spread samples using the sensory characteristics as regression variables in the model (Torrico and others 2015d).

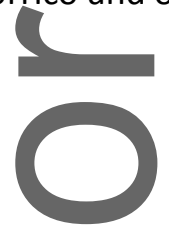

\section{Results and Discussion}

\section{Physical and textural properties of mayonnaise-type spreads}

ANOVA of physical and textural characteristics of the spreads is shown in Table 2. The main effects of the experimental design were: 1 . Tastant type $(\mathrm{NaCl}$ or $\mathrm{KCl})$, 2. Tastant concentration [0.50, 0.75 or $1.00 \%$ for $\mathrm{NaCl}$, and $0.50,1.00$ or $1.50 \%$ for $\mathrm{KCl}$, and 3 . Oil concentration $(45,55$ or $65 \%)$. Tastant and oil concentrations significantly $(P<0.05)$ affected viscosity and $\mathrm{pH}$. Type of tastant significantly $(P<0.05)$ affected $\mathrm{pH}$. Neither tastant nor oil concentrations significantly affected $(P \geq$ 0.05) water activity (data not shown). For all textural parameters, oil concentrations significantly 
affected all spreads. Additionally, tastant concentration was a significant $(P<0.05)$ factor for cohesiveness and resilience.

Overall, $\mathrm{NaCl}$ spreads had slightly higher viscosity compared to $\mathrm{KCl}$ spreads (6400-36395 cP vs. 5685-33545 CP, respectively; Table 3). For $\mathrm{NaCl}$ and/or $\mathrm{KCl}$ spreads, as oil concentration increased (from 45\% to 55\%), viscosity increased (11802-29045 cP; Table 3). Increasing tastant concentration had a slight viscosity-increasing effect on $\mathrm{NaCl}$ spreads (increase of $950-9145 \mathrm{cP}$, from $0.50 \%$ to $1.00 \% \mathrm{NaCl}$ ) but a viscosity-decreasing effect on $\mathrm{KCl}$ spreads (decrease of $8805-16058 \mathrm{cP}$, from $0.50 \%$ to $1.50 \% \mathrm{kCl}$. Increasing oil concentrations, increased viscosity and consistency of mayonnaise products (Wendin and others 1999). Changes in viscosity can affect taste perception of oil-in-water emulsions (Pripp and others 2004).

$\mathrm{KCl}$ spreads had higher $\mathrm{pH}$ values compared to $\mathrm{NaCl}$ spreads (4.47-4.55 vs. 4.40-4.42, Table 3). This demonstrated that $\mathrm{KCl}$ emulsions are more alkali than $\mathrm{NaCl}$ emulsions (Torrico and others 2015a). Tastant and oil concentrations did not have significant effects ( $P \geq 0.05$; Table 3 ) on pH for spreads.

$\mathrm{NaCl}$ spreads. For $\mathrm{KCl}$ spreads, increasing tastant concentration (from $0.50 \%$ to $1.50 \% \mathrm{KCl}$ ) minimally changed pH. The presence of minerals in emulsions increases the ionic strength of the aqueous phase. This effect leads to a reduction in the electrostatic repulsion between droplets and promotes phase separation. In emulsions, the degree of ionization and $\mathrm{pH}$ are important characteristics in determining emulsion stability (Kulmyrzaev and Schubert 2004). Poteau and Argillier (2005) indicated that $\mathrm{pH}$ changes may reduce stability of oil-in-water emulsions. Although, in the present study, the stability of the emulsions was not measured, changes in $\mathrm{pH}$ can potentially have an effect on shelf-life of spreads. Further studies have to be done to test this hypothesis.

For textural properties of spreads $(\mathrm{NaCl}$ and/or $\mathrm{KCl}$ ), as oil concentration increased (from $45 \%$ to $65 \%)$, cohesiveness, springiness, gumminess, resilience, and adhesiveness increased (Table 4). On the other hand, type of tastant $(\mathrm{NaCl}$ or $\mathrm{KCl})$ and tastant concentration had marginal effects on textural parameters of samples. Wendin and others (1999) indicated that all the rheological 
properties of mayonnaise products increased with increasing fat content. Moreover, Liu and others (2007) reported significant decreases in firmness, consistency, cohesiveness and viscosity when $50 \%$ oil was replaced with micro-particulated pectin gel in mayonnaise formulations. In the present study, oil had a significant effect on changing viscosity and textural properties of emulsions. On the other hand, the type of tastant was a determinant factor on changing $\mathrm{pH}$ of spreads. Water activity $\left(\mathrm{a}_{\mathrm{w}}\right)$ was not affected by any of these factors, and remained constant for all spreads (0.93-0.95; data not shown).

\section{ऽ}

\section{Sensory analysis of mayonnaise-type spreads}

Saltiness

ANOVA for the saltiness intensity of spread samples (Table 2 ) indicates that the main effects [tastant type, tastant concentration, oil concentration] and the interaction effect between tastant type and oil concentration were significant $(P<0.05)$. Overall, $\mathrm{NaCl}$ spreads had slightly higher saltiness intensities compared to $\mathrm{KCl}$ spreads (Table 3). As expected, saltiness intensity increased as tastant ( $\mathrm{NaCl}$ and/or $\mathrm{KCl})$ concentration increased. Generally, saltiness intensity of spreads $(\mathrm{NaCl}$ and/or $\mathrm{KCl}$ ) decreased slightly (3.01-8.26 units) as oil concentration increased (from $45 \%$ to $65 \%$; Table 3).

Table 5 shows the estimated parameters of predictive regression models for saltiness of $\mathrm{NaCl}$ and $\mathrm{KCl}$ spreads The linear and total model effects were significant $(P<0.05)$ for both spreads. The quadratic effect was only significant for $\mathrm{NaCl}$ spreads. Linear parameters for tastant and oil concentrations of $\mathrm{NaCl}$ spreads were 69.71 and -4.02 , respectively (i.e., an increase of $0.1 \% \mathrm{NaCl}$ represented an increase of 6.97 intensity units; an increase of $1.0 \%$ oil represented a decrease of 4.02 intensity units). Similar to $\mathrm{NaCl}, \mathrm{KCl}$ linear slope for tastant concentration was positive (8.98), indicating that as tastant concentration increased by $0.1 \% \mathrm{KCl}$, saltiness intensity increased by 0.90 units. Contrary to $\mathrm{NaCl}$, increasing oil concentrations (linear slope of 2.00 ) in $\mathrm{KCl}$ spreads slightly 
increased saltiness. Predictions on taste using linear correlations are limited by the range of concentrations evaluated in this study $(0.5 \%-1.0 \%$ for $\mathrm{NaCl}$, and $0.5 \%-1.5 \%$ for $\mathrm{KCl})$. $\mathrm{NaCl}$ saltiness contour plots (Figure 1) indicated that oil exhibited a saltiness-suppressing effect in spreads with $45 \%$ to $59 \%$ oil; however, oil had a saltiness-enhancing effect in spreads with $60 \%$ oil or higher. The opposite pattern occurred with $\mathrm{KCl}$ (Figure 1), in which, oil exhibited a saltiness-enhancing effect in spreads with $45 \%$ to $53 \%$ oil; however, oil showed a saltiness-suppressing effect in spreads with $54 \%$ oil or higher

Hughes and Others (1997) reported that oils as hydrophobic compounds can act as physical barriers against sodium migration, disfavoring sodium release. Oil was also found to coat the tongue surface; thus, preventing taste buds from accessing sodium in the oral cavity (Lynch and others 1993). These mechanisms may partially explain the saltines-suppressing effect imparted by oil for $\mathrm{NaCl}$ spreads in the present study. On the other hand, another study reported that oil components may sensitize sodium taste receptors, enhancing saltiness perception (Gilbertson and others 2005). Koriyama and others (2002) hypothesized that lipids in emulsions occupy volume that does not contain $\mathrm{NaCl}$ or $\mathrm{KCl}$ molecules, which are $100 \%$ partitioned in the aqueous phase. Therefore, increased perceived taste intensities are found in emulsions with higher oil concentrations (Kuo and Lee 2014; Koriyama and others 2002). In the present study, this effect may have been the case for $\mathrm{KCl}$ spreads with $45-53 \%$ oil, in which, increased oil concentrations produced increased saltiness

Bitterness

ANOVA for the bitterness intensity (Table 2) shows that only the tastant concentration effect was significant $(P<0.05)$ in differentiating spread samples. Although $\mathrm{KCl}$ is known to impart bitter taste (Hooge and Chambers 2010), all emulsion systems (including $\mathrm{NaCl}$ spreads) presented perceivable bitterness regardless of tastant and oil concentrations (Table 3). Bitterness in $\mathrm{NaCl}$ spreads can be 
explained due to the presence of other ingredients including vinegar, whey protein and gums in the emulsion formulations. Overall, $\mathrm{KCl}$ spreads had slightly higher bitterness intensities compared to that of $\mathrm{NaCl}$ spreads (16.90-25.61 vs. 21.24-31.30; Table 3). For $\mathrm{KCl}$ spreads, bitterness intensity increased (3.04-10.06 units), as tastant concentration increased (from $0.50 \%$ to $1.50 \% \mathrm{KCl}$; Table 3). The opposite effect occurred with $\mathrm{NaCl}$ spreads, in which, bitterness intensity decreased (2.46-6.94 units) with increasing tastant concentrations (from $0.50 \%$ to $1.00 \% \mathrm{NaCl}$; Table 3). Generally for both spreads ( $\mathrm{NaCl}$ and/or $\mathrm{KCl}$ ), oil had marginally effects on bitterness intensity (Table 3).

For RSM bitterness predictive models (Table 5), the $\mathrm{NaCl}$ linear and total model effects were significant $(P<0.05)$. None of the regression effect parameters were significant for $\mathrm{KCl}$ (Table 5). The $\mathrm{NaCl}$ linear slopes for tastant and oil concentrations were 64.94 and -1.12 , respectively. This indicated that increasing $\mathrm{NaCl}$ concentration by $0.1 \%$, increased bitterness intensity by 6.49 units. On the other hand, increasing oil concentration by $1.0 \%$, decreased bitterness by 1.12 units. Similar to $\mathrm{NaCl}, \mathrm{KCl}$ linear slope for tastant concentration was positive (10.48; Table 5) indicating that increasing $\mathrm{KCl}$ concentration by $0.1 \%$, marginally increased bitterness intensity by 1.05 units. Contrary to $\mathrm{NaCl}$, oil concentration (linear slope 2.32 ) in $\mathrm{KCl}$ spreads had a slight enhancing effect on bitterness.

Although the $\mathrm{NaCl}$ linear slope was positive (64.94; Table 5), its contour plot (Figure 1 ) indicated that increasing $\mathrm{NaCl}$ concentration had, in fact, a suppressing effect on bitterness. This can be explained due to the presence of a marginal negative quadratic effect $(-32.24$; Table 5$)$ in $\mathrm{NaCl}$ spreads, in which, as oil concentration increased, bitterness of samples decreased. Breslin and Bauchamp (1995) demonstrated that sodium suppressed bitterness in solution systems. In the present study, a bitterness-suppressing effect was more noticeable when concentrations of $\mathrm{NaCl}$ increased (Table 3).

Thurgood and Martini (2010) indicated that bitterness intensities were lower in emulsion systems compared to solutions. Pripp and others (2004) reported that oil had a limited effect on bitterness 
reduction of olive oil phenolic compounds. Metcalf and Vickers (2002) stated that samples with added oil had less bitter taste and more saltiness intensity than those with added water. The suppression of bitterness by fat/oil is not universal and depends on the properties of the molecules responsible for the bitter taste (Coupland and Hayes 2014). Lahtinen and others (2007) showed that lactose $(1 \%$ or $2 \%)$ in combination with sucrose, glucose or galactose suppressed bitter tastes of $\mathrm{NaCl} / \mathrm{KCl}$ mixtures in emulsions. Keast (2008) stated that the level of caffeine bitterness increased with increases of milk fat content. He attributed this effect to interactions of caffeine molecules with milk proteins and carbohydrates. In the present study, oil had a marginal effect on taste, and the main contributor to reduce bitterness in the systems was the increase of $\mathrm{NaCl}$ concentrations. Our previous findings showed that oil had a significant bitterness-suppressing effect in emulsion systems (Torrico and others 2015b; Torrico and others 2015c). Differences among studies may be due to the interaction of other ingredients (vinegar, protein and emulsifiers) that affected taste perception. For example, Keast and Breslin (2003) stated that bitterness in solutions was enhanced with the (a) soun introduction of sourness, using a binary system at low and medium intensities. Further research is needed to investigate the effects of binary and tertiary interactions on taste perception of oil-inwater emulsions.

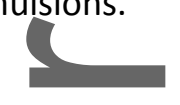

\section{Overall taste liking, penalty analysis and purchase intent of mayonnaise-type spreads}

ANOVA for the overall taste liking (Table 2) indicated that tastant type and tastant concentration effects were significant $(P<0.05)$ in differentiating spread samples. Overall taste liking scores for all mayonnaise-type spreads ( $\mathrm{NaCl}$ and/or $\mathrm{KCl}$ ) were generally low (below 5; Table 3). Overall, $\mathrm{NaCl}$ spreads had slightly higher scores compared to that of $\mathrm{KCl}$ spreads (Table 3). Oil concentration had a marginal effect on liking scores.

Maximizing acceptability of spreads was not the intended scope of this study. We aimed to evaluate variations in liking depending on changes in oil concentration and the type of tastant used 
in the spread formulations. A penalty analysis was performed to identify attributes and samples that were responsible for reductions in acceptance. Figure 2 shows the total penalty scores of spread samples ( $\mathrm{NaCl}$ and/or $\mathrm{KCl}$ ) according to viscosity, saltiness, and bitterness. Attributes with scores greater than 0.5 can potentially affect consumer acceptability (Walker 2016). For viscosity, all spreads were generally considered "too thick", whereas $\mathrm{KCl}$ spreads had higher penalty scores compared to $\mathrm{NaCl}$ spreads (0.01-1.12 for $\mathrm{KCl}$ vs. $0.05-0.64$ for $\mathrm{NaCl}$; Figure 2). For saltiness, "too week" penalty scores (0.18-1.20) were similar compared to that of "too strong" scores (0.19-1.15) for all spreads (Figure 2). There was not a clear trend in penalizing saltiness since consumers taste liking was divided (possibly by likers and dislikers of saltiness among consumers). In general, $\mathrm{KCl}$ spreads with higher oil concentrations ( $55 \%$ and $65 \%$ ) had higher "too weak" saltiness penalty scores compared to other spreads (Figure 2). The $\mathrm{NaCl}(0.5 \%)-O i l(65 \%)$ spread sample had the lowest saltiness intensity score (16.28; Table 3) and the highest "too weak" saltiness penalty score (1.20) among all $\mathrm{NaCl}$ spreads. Similarly, the $\mathrm{KCl}(0.50 \%)-0 i l(65 \%)$ spread sample had the lowest saltiness intensity score (12.25; Table 3 ) and the second highest "too weak" saltiness penalty score $(0.85)$ among all $\mathrm{KCl}$ spreads. Interestingly, the $\mathrm{KCl}(1.50 \%)-O i l(45 \%)$ spread sample had the highest saltiness intensity score (24.88; Table 3 ) among all $\mathrm{KCl}$ spreads. However, $33.33 \%$ (data not shown) of consumers assessed saltiness of this sample as "too week" and $37.25 \%$ (data not shown) of consumers assessed the saltiness of this sample as "too strong" (showing the polarizing effect of saltiness on $\mathrm{KCl}$ samples). This resulted in similar penalty scores for both categories (1.19 for "too week" and 1.15 for "too strong"). All mayonnaise-type spreads were generally considered "too strong" in bitterness, whereas $\mathrm{KCl}$ spreads had higher penalty scores (0.61-1.48) compared to those of $\mathrm{NaCl}$ spreads (0-1.28). Of all spreads, only $\mathrm{NaCl}(1.00 \%)-\mathrm{Oil}(55 \%)$ and $\mathrm{NaCl}(0.50 \%)-\mathrm{Oil}(55 \%)$ had bitterness penalty scores less than 0.5 ; in fact, these samples had higher overall taste liking scores (4.21-4.70) compared to other samples (3.36-4.41). 
For mayonnaise-type spreads ( $\mathrm{NaCl}$ or $\mathrm{KCl})$, logistic regression was performed to predict positive purchase intent, considering emulsions characteristics (tastant and oil concentrations) and sensory attributes (saltiness, bitterness, and overall liking) (Table 6). Overall taste liking was the most influential attribute affecting purchase intent for all spreads (odds ratio $=3.554$ for $\mathrm{NaCl}$ and 3.829 for $\mathrm{KCl}$ emulsions). The higher odds ratio for predicting purchase intent of $\mathrm{KCl}$ spreads could be explained by the-importance of taste liking expressed by consumers in those samples. These results are consistent with the penalty analysis, in which, $\mathrm{KCl}$ spreads had higher penalizations on taste liking compared to that of $\mathrm{NaCl}$ (Figure 2). Only for $\mathrm{NaCl}$ spreads, oil concentration was the second most influential attribute for predicting purchase intent (odds ratio $=1.047$ ), meaning that an increase of $1 \%$ in oil concentration represented an increase of $4.7 \%$ in the predicated purchasing intent of spreads.

Garcia and others (2009) indicated that mouthfeel and overall liking were the two most influential sensory attributes on the acceptance of mayonnaise-type spreads made with rice bran oil and soy protein. Izidoro and others (2007) reported that regular mayonnaise product possessed higher acceptability scores compared to that of low-fat mayonnaise products. Mihov and others (2012) reported that high fat mayonnaise products obtained higher acceptability scores for appearance and taste compared to low fat product versions. In our present study, overall taste liking of the spreads was strongly affected by type of tastant. Generally, spreads containing $\mathrm{KCl}$ were highly penalized in taste liking for being too bitter. The lower taste acceptability resulted in a decrease in purchase intent of spreads (Lawless \& Heymann, 2010). However, oil concentration also played an important role on assessing purchase intent of spreads containing $\mathrm{NaCl}$.

\section{Multivariate analysis}

The results obtained by the cluster analysis of 18 mayonnaise-type spreads considering 3 sensory (saltiness, bitterness and overall liking), 3 physical ( $\mathrm{pH}$, water activity, and viscosity) and 5 textural 
(cohesiveness, gumminess, springiness, resilience, and adhesiveness) attributes are presented as the dendrogram in Figure 3. Two main cluster groups were observed: (1) $45 \%$ and $55 \%$ oil spreads and (2) $65 \%$ oil spreads. These results indicated that the main differentiating factor among spreads was the oil concentration. $\mathrm{NaCl}(1.00 \%)-\mathrm{Oil}(45 \%)$ and $\mathrm{NaCl}(0.75 \%)-\mathrm{Oil}(45 \%)$ had the smallest intercluster distance indicated by the vertical line linking them. Subsequently, other minor clusters (distance between clusters < 3 ; Figure 3 ) were formed among $45 \%$ and $55 \%$ oil spreads. The bi-plot (Figure 4) describes the principal component analysis, considering the relative position of spread samples and sensory/physical/textural attributes (70.85\% of total variability). In terms of the sensory attributes, the bitterness vector points to the opposite direction of overall taste liking vector, meaning that these two attributes were negatively correlated (a higher bitterness produced a lower overall taste liking). On the other hand, saltiness was marginally correlated to bitterness and overall taste liking. For physical attributes, pH was negatively correlated with water activity. Viscosity, on the other hand, was not correlated with any other physical attribute. For textural attributes, cohesiveness, springiness, and resilience were positively correlated (higher cohesiveness produced higher springiness and resilience). Viscosity was positively correlated with cohesiveness, gumminess, springiness and resilience. Interestingly, $\mathrm{pH}$ was positively correlated with bitterness and negatively correlated with overall taste liking. Our previous investigation demonstrated that $\mathrm{KCl}$ systems (solutions and emulsions) possessed higher $\mathrm{pH}$ and bitterness values compared to that of $\mathrm{NaCl}$ systems (Torrico and others 2015a). Fontoin and others (2008) reported that increasing pH values did not have a significant effect on bitterness of wine solutions. Seki and others (1990) reported that cris increasing $\mathrm{pH}$ values of solutions produced decreases in saltiness perception. Further work has to be done to elucidate the effects of $\mathrm{pH}$ on taste perception of oil-in-water emulsions.

In the present study, two mayonnaise-type spread groups were clearly separated along principal component 1 (65\% oil and 45-55\% oil spreads; Figure 4), considering all sensory/physical/textural attributes altogether. This result is in agreement with the finding from the cluster analysis (Figure 3 ). 
For the PCA (Figure 4), textural (cohesiveness, gumminess, springiness, and resilience) and viscosity parameters were the larger contributors to the differences among spread samples.

Collectively, based on Tables 2, 5 and 6, and Figures 1 and 4, the results indicated that oil concentration affected saltiness, viscosity, $\mathrm{pH}$ and consistency/texture of mayonnaise-type spreads. Moreover, oil concentration was a significant factor for predicting purchase intent of spreads containing $\mathrm{NaCl}$, and was the main factor that contributed to the overall differences of the spreads, considering all sensory, physical and textural attributes, altogether.

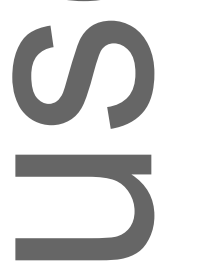

This study demonstrated that oil and tastant ( $\mathrm{NaCl}$ and/or $\mathrm{KCl}$ ) concentrations had significant effects on saltiness, viscosity, and $\mathrm{pH}$. Generally, as oil concentration increased, saltiness perception slightly decreased for spreads. Oil had a marginal effect on bitterness. Increasing oil concentration increased viscosity. Spreads containing $\mathrm{KCl}$ had higher bitterness than spreads containing $\mathrm{NaCl}$. Bitterness of spreads containing $\mathrm{KCl}$ increased with increasing oil concentrations, which resulted in higher penalizations for overall taste liking. Purchase intent was significantly affected by taste liking for all spreads but oil concentration was also a significant factor in the purchase decision of spreads containing $\mathrm{NaCl}$ This study demonstrated that increasing oil and tastant concentrations affected consumers' taste perception (saltiness and bitterness) and spreads' physical properties including pH and viscosity. These findings are useful for understanding consumers' taste perception of oil-inwater emulsion products.

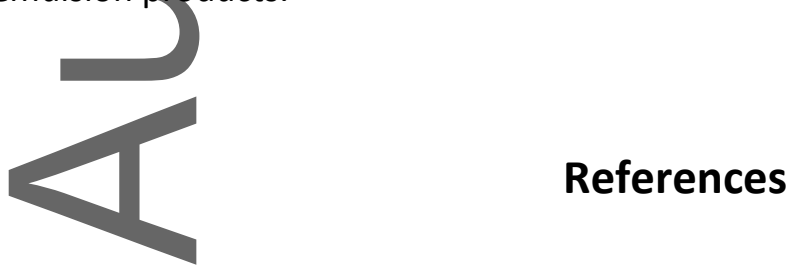

Appel L, Frohlich ED, Hall JE, Pearson TA, Sacco RL, Seals DR, Sacks FM, Smith SD, Vafiadis DK, Van Horn LV. 2011. The importance of population-wide sodium reduction as a means to prevent 
cardiovascular disease and stroke. A call to action from the American Heart Association. Circulation 123(10):1138-43. doi: 10.1161/CIR.0b013e31820d0793

Bourne MC. 1978. Texture profile analysis. Food Technol 32 (7):62-6.

Breslin PAS, Beauchamp GK. 1995. Suppression of bitterness by sodium: Variation among bitter taste stimuli. Chem senses 20(6):609-23. doi: 10.1093/chemse/20.6.609

Busch JLHG, Yong FYS, Goh SM. 2013. Sodium reduction: Optimizing product composition and structure toward increasing saltiness perception. Trends Food Sci Tech 29(1):2134 doi: 10.1016/j.tifs.2012.08.005

[CDC]. Centers for Disease Control and Prevention. 2016. Division for heart disease and stroke prevention. Available from: http://www.cdc.gov/dhdsp/programs/sodium reduction.htm. Accessed January 25, 2017.

Coupland JN, Hayes JE. 2014. Physical approaches to masking bitter taste: Lessons from food and pharmaceuticals. Pharm Res 31(11):2921-39. doi: 10.1007/s11095-014-1480-6

Deman JM. 1976. Principles of Food Chemistry. Connecticut: AVI Publishing. 426 p.

Fontoin H, Saucier C, Teissedre P-L, Glories Y. 2008. Effect of pH, ethanol and acidity on astringency and bitterness of grape seed tannin oligomers in model wine solution. Food Qual Prefer 19(3):286-91. doi: 10.1016/j.foodqual.2007.08.004

Fuentes S. (Unpublished). Development of a customized code written in Matlab used for multivariate data analysis based on principal component analysis and cluster analysis algorithms.

Garcia K, Sriwattana S, No HK, Corredor JAH, Prinyawiwatkul W. 2009. Sensory optimization of a mayonnaise-type spread made with rice bran oil and soy protein. J Food Sci 74(6):S248-54. do: $10.1111 / \mathrm{j} .1750-3841.2009 .01203 . x$

Gilbertson TA, Liu L, Kim I, Burks CA, Hansen DR. 2005. Fatty acid responses in taste cells from obesity-prone and -resistant rats. Physiol Behav 86(5):681-90. doi: 10.1016/j.physbeh.2005.08.057 
Green BG, Shaffer GS, Gilmore MM. 1993. Derivation and evaluation of a semantic scale of oral sensation magnitude with apparent ratio properties. Chem Senses 18(6):683-702. doi: 10.1093/chemse/18.6.683

Heshmati A. 2014. Evaluation of heavy metals contamination of unrefined and refined table salt. Int J Res Stud Biosci 2(2):21-24.

Hooge S, Chambers D. 2010. A comparison of basic taste modalities, using a descriptive analysis technique, for varying levels of sodium and $\mathrm{KCl}$ in two model soup systems. J Sens Stud 25(4):521-35. doi: 10.1111/j.1745-459X.2010.00284.x

Hughes E, Cofrades S, Troy DJ. 1997. Effects of fat level, oat fiber and carrageenan on frankfurters formulated with 5, 12 and 30\% fat. Meat Sci 45(3):273-81. doi: 10.1016/S0309$1740(96) 00109-x$

Izidoro D, Sierakowski M-R, Waszczynskyj N, Haminiuk CW, Scheer AdP. 2007. Sensory evaluation and rheological behavior of commercial mayonnaise. Int J Food Eng 3(1):1-15. doi: $10.2202 / 1556-3758.1094$

Keast RSJ. 2008. Modification of the bitterness of caffeine. Food Qual Prefer 19(5): 465-72. doi: 10.1016/j.foodqual.2008.02.002

Keast RSJ, Breslin PAS. 2003. An overview of binary taste-taste interactions. Food Qual Prefer 14(2):111-24. doi: 10.1016/S0950-3293(02)00110-6

Kilcast D, den Ridder C. 2007. Sensory issues in reducing salt in food products. In: Kilcast D, Angus F, editors. Reducing salt in foods-Practical strategies. Cambridge, UK: Woodhead Publishing. $p$ $201-20$. $201-20$.

Koriyama T, Wongso S, Watanabe K, Abe H. 2002. Fatty acid compositions of oil species affect the 5 taste perceptions. J Food Sci 67(2):868-73. doi: 10.1111/j.1365-2621.2002.tb10691.x 
Kulmyrzaev AA, Schubert H. 2004. Influence of $\mathrm{KCl}$ on the physicochemical properties of whey protein stabilized emulsions. Food Hydrocolloids 18(1):13-9. doi: 10.1016/S0268(1) $005 \times(03) 00037-7$

Kuo W, Lee Y. 2014. Effect of Food Matrix on Saltiness Perception-Implications for Sodium Reduction. Compr Rev Food Sci F 13(5):906-23. doi: 10.1111/1541-4337.12094

Lahtinen SJ, Ouwehand AC, Salminen SJ, Forssell P, Myllärinen P. 2007. Effect of starch-and lipidbased encapsulation on the culturability of two Bifidobacterium longum strains. Lett Appl Microbiol 44(5):500-5. doi: 10.1111/j.1472-765X.2007.02110.x

Lawless HT, Heymann H. 2010. Sensory evaluation of food: Principles and practices: Springer New York.

Liem DG, Miremadi F, Keast R. 2011. Reducing sodium in foods: The effect on flavor. Nutrients 3(6):694-711. doi: 10.3390/nu3060694

Lin GC, Mittal GS, Barbut S. 1991. Optimization of tumbling and $\mathrm{KCl}$ substitution in low sodium restructured restructured hams. J Muscle Foods 2(2):71-91. doi: 10.1111/j.1745-4573.1991.tb00444.x

Lipkovich 1, Smith EP. 2001. Biplot and singular value decomposition macros for Excel. J Stat Software 7(5):1-15. doi: 10.18637/jss.v007.i05

Liu H, Xu XM, Guo SD. 2007. Rheological, texture and sensory properties of low-fat mayonnaise with different fat mimetics. LWT - Food Sci Technol 40(6):946-54. doi: 10.1016/j.Iwt.2006.11.007 Lynch J, Liu YH, Mela DJ, MacFie HJH. 1993. A time-intensity study of the effect of oil mouthcoatings on taste perception. Chem Senses 18(2):121-9. doi: 10.1093/chemse/18.2.121

Metcalf KL, Vickers ZM. 2002. Taste intensities of oil-in-water emulsions with varying fat content. J Sens Stud 17(5):379-90. doi: 10.1111/j.1745-459X.2002.tb00354.x

Mihov R, Nikovska K, Nenov N, Slavchev A. 2012. Evaluation of mayonnaise-like food emulsions with extracts of herbs and spices. Emir J Food Agr 24(3):191-9. 
Murphy C, Cardello AV, Brand J. 1981. Tastes of fifteen halide salts following water and $\mathrm{NaCl}$ : anion and cation effects. Physiol Behavior 26:1083-95. doi: 10.1016/0031-9384(81)90213-4

Peryam DR, Pilgrim FJ. 1957. Hedonic scale method of mea-suring food preferences. Food Technol $11: 9-14$.

Poteau S, Argillier J-F, Langevin D, Pincet F, Perez E. 2005. Influence of pH on Stability and Dynamic Properties of Asphaltenes and Other Amphiphilic Molecules at the Oil-Water Interface. Energ Fuel 19(4):1337-41. doi: 10.1021/ef0497560

Pripp AH, Busch J, Vreeker R. 2004. Effect of viscosity, sodium caseinate and oil on bitterness perception of olive oil phenolics. Food Qual Prefer 15(4):375-82. doi: 10.1016/S0950$3293(03) 00084-3$

SAS (2012). SAS/STAT User's Guide. Version 9.4. Cary, NC: SAS Institute Inc.

Sae-Eaw A, Compreeda P, Prinyawiwatkul W, Haruthaithanasan V, Suwonsichon T, Saidu JE, Xu Z. 2007. Aeceptance and purchase intent of US consumers for non wheat rice butter cakes. J Food Sci 72(2):92-7. doi: 10.1111/j.1750-3841.2006.00256.x

Seman DL, Olson DG, Mandigo RW. 1980. Effect of reduction and partial replacement of sodium on bologna characteristics and acceptability. J Food Sci 45(5):1116-21. doi: 10.1111/j.13652621.1980.tb06500.x

Seki T, Kawasaki Y, Tamura M, Tada M, Okai H. 1990. Further study on the salty peptide ornithyl- $\beta$ alanine Some effects of pH and additive ions on the saltiness. J Agric Food Chem 38(1):25-9. doi: 10.1021/jf00091a005

Shamil S, Wyeth $L$, Kilcast D. 1991-1992. Flavour release and perception in reduced-fat foods. Food Qual Prefer 3(1):51-60. doi: 10.1016/0950-3293(91)90023-8

Torrico DD, Carabante KM, Pujols KD, Chareonthaikij P, Prinyawiwatkul W. 2015a. Oil and tastant concentrations affect saltiness and bitterness perception of oil-in-water emulsions. Int J Food Sci Technol 50(12):2562-71. doi: 10.1111/ijfs.12924 
Torrico DD, Prinyawiwatkul W. 2015b. Psychophysical Effects of Increasing Oil Concentrations on Saltiness and Bitterness Perception of Oil-in-Water Emulsions. J Food Sci 80(8):S1885-92. do: $10.1111 / 1750-3841.12945$

Torrico DD, Sae-Eaw A, Sriwattana S, Boeneke C, Prinyawiwatkul W. 2015c. Oil-in-water emulsion

exhibits bitterness-suppressing effects in a sensory threshold study. J Food Sci 80(6):S140411. doi: $10.1111 / 1750-3841.12901$

Torrico DD, Wardy W, Pujols KD, Carabante KM, Jirangrat W, Scaglia G, Janes ME, Prinyawiwatkul W. 2015d. Cross-Cultural Consumer Acceptability and Purchase Intent of Forage-Finished RibEye Steaks.J Food Sci 80(10):S2287-95. doi: 10.1111/1750-3841.12999

Thurgood JE, Martini S. 2010. Effects of three emulsion compositions on taste thresholds and intensity ratings of five taste compounds. J Sens Stud 25(6):861-75. doi: 10.1111/j.1745459X.2010.00311.x

Walker L. 2016. Using penalty analysis as an aid in product development. White paper Development resources. FONA International, Inc. Available from: http://www.fona.com/sites/default/files/WhitePaper Penalty\%20Analysis sensory.pdf.

Accessed January 25, 2016.

Wendin K, Ellekjær MR, Solheim R. 1999. Fat content and homogenization effects on flavour and texture of mayonnaise with added aroma. Food Sci Technol-Leb 32(6):377-83. doi: $10.1006 /$ fstl.1999.0562

Wendin K, Langton M, Caous L, Hall G. 2000. Dynamic analyses of sensory and microstructural properties of cream cheese. Food chem 71(3):363-78. doi: 10.1016/S0308-8146(00)00200-4

Table 1 Formulations of mayonnaise-type spreads made with canola oil

\begin{tabular}{ccccc}
\hline Formulations $^{1}$ & Oil (\%) & $\mathrm{NaCl}(\%)$ & $\mathrm{KCl}(\%)$ & Water (\%) \\
\hline $\mathrm{NaCl}(0.50 \%)-O i l(45 \%)$ & 45 & 0.50 & 0.00 & 39.45 \\
$\mathrm{NaCl}(0.75 \%)-O i l(45 \%)$ & 45 & 0.75 & 0.00 & 39.20
\end{tabular}




$\begin{array}{lllll}\mathrm{NaCl}(1.00 \%)-O i l(45 \%) & 45 & 1.00 & 0.00 & 38.95 \\ \mathrm{NaCl}(0.50 \%)-O i l(55 \%) & 55 & 0.50 & 0.00 & 29.45 \\ \mathrm{NaCl}(0.75 \%)-O i l(55 \%) & 55 & 0.75 & 0.00 & 29.20 \\ \mathrm{NaCl}(1.00 \%)-O i l(55 \%) & 55 & 1.00 & 0.00 & 28.95 \\ \mathrm{NaCl}(0.50 \%)-O i l(65 \%) & 65 & 0.50 & 0.00 & 19.45 \\ \mathrm{NaCl}(0.75 \%)-O i l(65 \%) & 65 & 0.75 & 0.00 & 19.20 \\ \mathrm{NaCl}(1.00 \%)-O i l(65 \%) & 65 & 1.00 & 0.00 & 18.95 \\ \mathrm{KCl}(0.50 \%)-O i l(45 \%) & 45 & 0.00 & 0.50 & 39.45 \\ \mathrm{KCl}(1.00 \%)-O i l(45 \%) & 45 & 0.00 & 1.00 & 38.95 \\ \mathrm{KCl}(1.50 \%)-0 i l(45 \%) & 45 & 0.00 & 1.50 & 38.45 \\ \mathrm{KCl}(0.50 \%)-O i l(55 \%) & 55 & 0.00 & 0.50 & 29.45 \\ \mathrm{KCl}(1.00 \%)-0 i l(55 \%) & 55 & 0.00 & 1.00 & 28.95 \\ \mathrm{KCl}(1.50 \%)-0 i l(55 \%) & 55 & 0.00 & 1.50 & 28.45 \\ \mathrm{KCl}(0.50 \%)-O i l(65 \%) & 65 & 0.00 & 0.50 & 19.45 \\ \mathrm{KCl}(1.00 \%)-O i l(65 \%) & 65 & 0.00 & 1.00 & 18.95 \\ \mathrm{KCl}(1.50 \%)-O i l(65 \%) & 65 & 0.00 & 1.50 & 18.45\end{array}$
${ }^{1}$ All treatments had fixed concentrations of vinegar (8.90\%), whey protein isolate $(5.4 \%)$, and Tic
Gum $(0.75 \%)$.

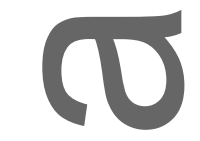

Table 2 ANOVA $^{1}$ table for the sensory, physical, and textural characteristics of spreads

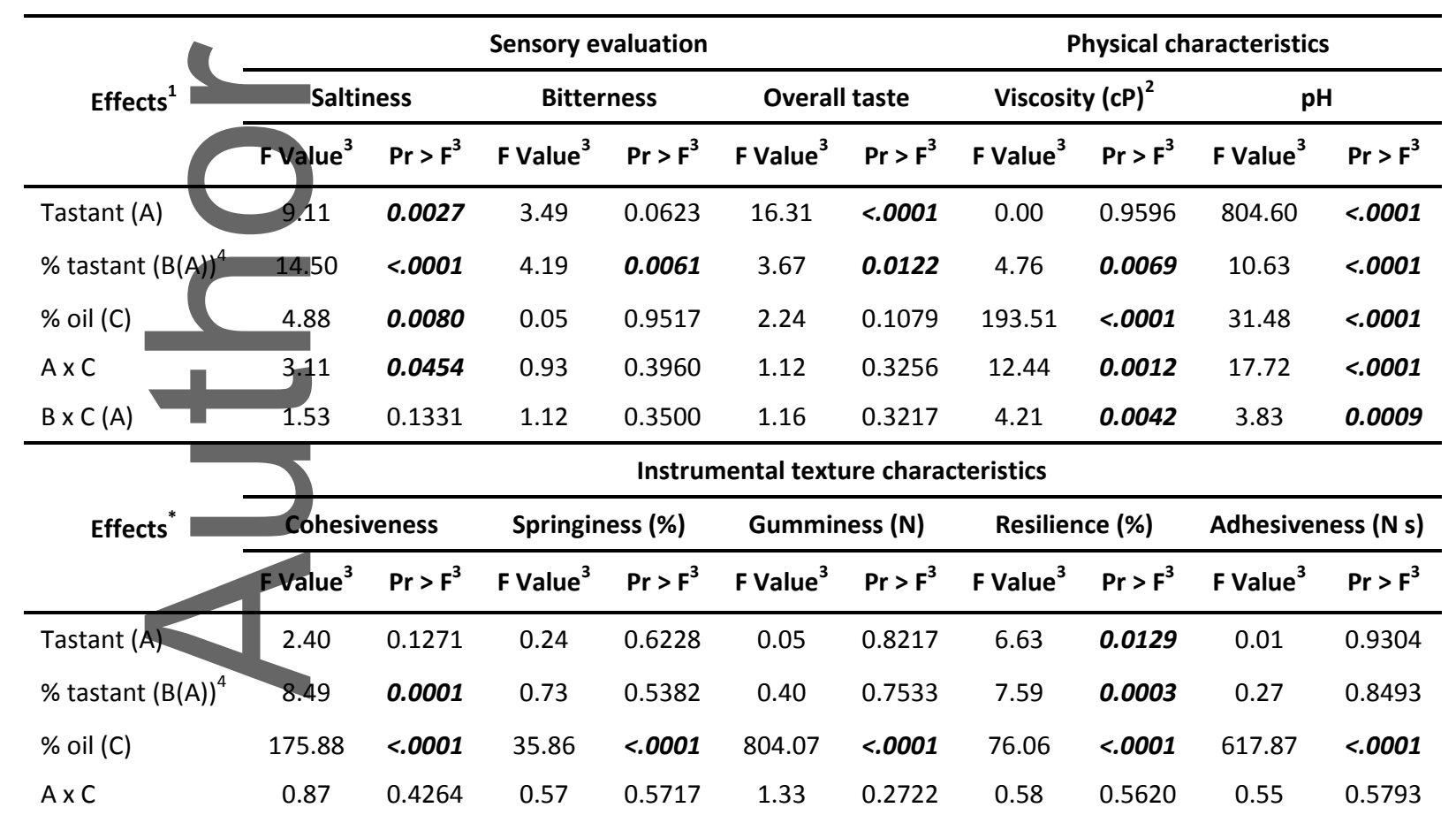




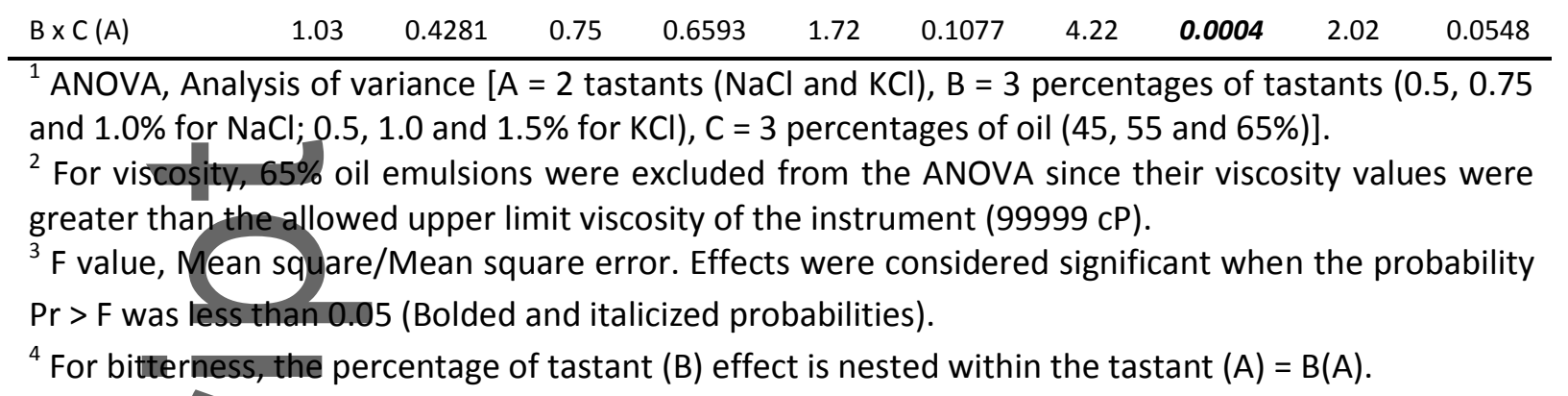

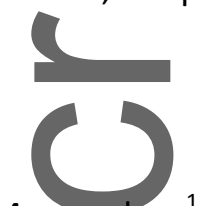

Table 3 Mean values ${ }^{1}$ for spreads sensory and physical characteristics

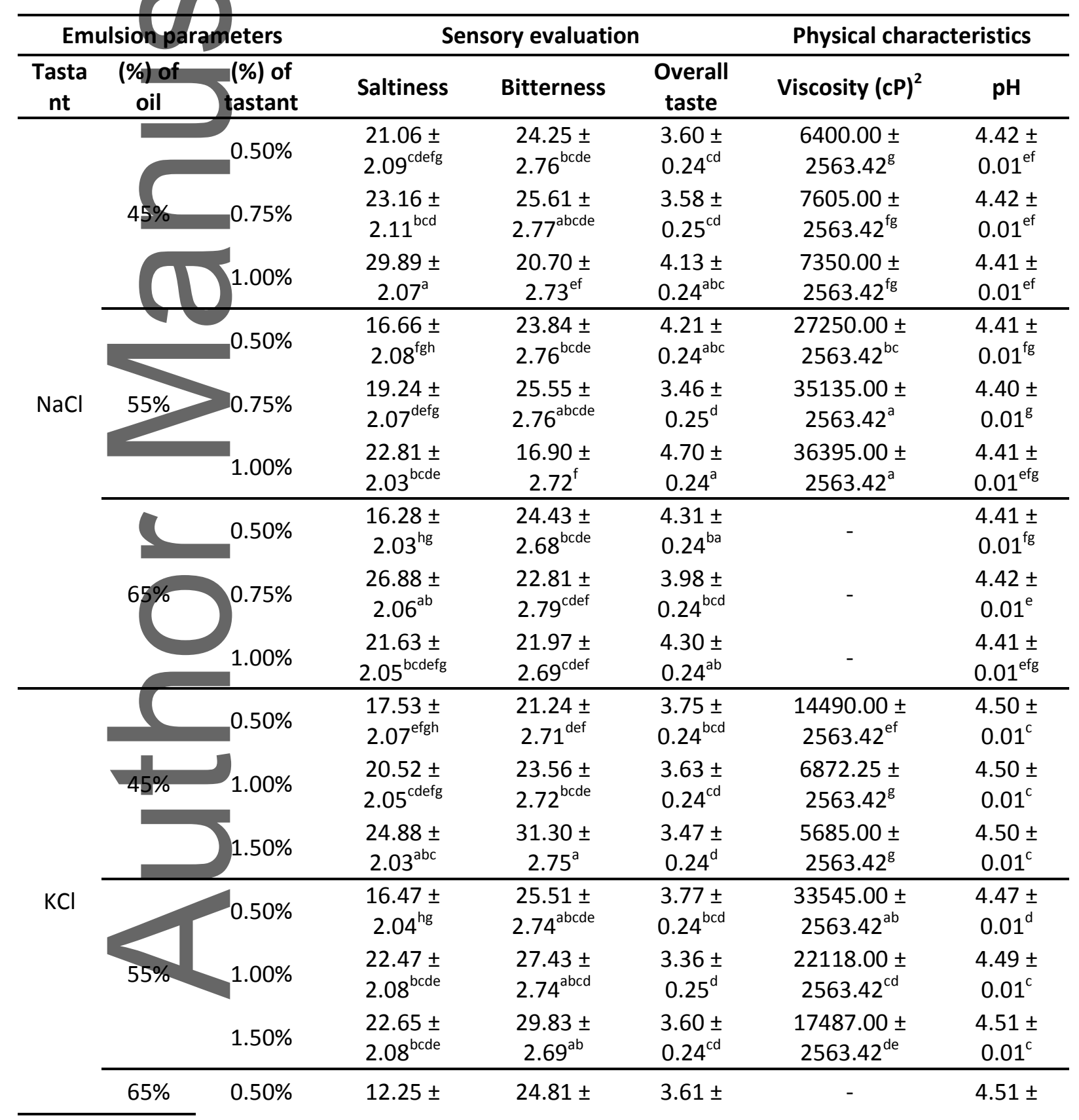

This article is protected by copyright. All rights reserved. 


\begin{tabular}{rccccc} 
& $2.06^{\mathrm{h}}$ & $2.73^{\text {abcde }}$ & $0.24^{\text {cd }}$ & & $0.01^{\mathrm{c}}$ \\
& $18.56 \pm$ & $25.09 \pm$ & $3.82 \pm$ & & $4.53 \pm$ \\
$1.00 \%$ & $2.08^{\text {defg }}$ & $2.77^{\text {abcde }}$ & $0.25^{\text {bcd }}$ & - & $0.01^{\mathrm{b}}$ \\
& $21.87 \pm$ & $27.85 \pm$ & $3.83 \pm$ & - & $4.55 \pm$ \\
$1.50 \%$ & $2.05^{\text {bcdef }}$ & $2.70^{\text {abc }}$ & $0.24^{\text {bcd }}$ & - & $0.01^{\mathrm{a}}$ \\
\hline
\end{tabular}

${ }^{1}$ Data are represented as mean and standard error values $(\mathrm{N}=51$ for sensory and $\mathrm{N}=2$ for physical characteristics). For saltiness and bitterness, values are based on a 100-points Labeled Magnitude Scale (LMS) scale. Overall taste liking scores were based on a 9-point hedonic scale.

a-h Mean values with the same letter within the same column are not significantly different $(P \geq$ 0.05).

${ }^{2}$ For viscosity, $65 \%$ oil emulsions were excluded since their viscosity values were greater than the allowed upper limit viscosity of the instrument (99999 cP).

Table 4 Mean yalues ${ }^{1}$ for spreads textural characteristics

\begin{tabular}{|c|c|c|c|c|c|c|c|}
\hline \multicolumn{3}{|c|}{ Emulsion parameters } & \multicolumn{5}{|c|}{ Textural characteristics } \\
\hline $\begin{array}{c}\text { Tasta } \\
\text { nt }\end{array}$ & $(\%)$ & $\begin{array}{l}\text { (\%) of } \\
\text { tastant }\end{array}$ & $\begin{array}{c}\text { Cohesiven } \\
\text { ess }\end{array}$ & $\begin{array}{c}\text { Springiness } \\
(\%)\end{array}$ & $\begin{array}{c}\text { Gumminess } \\
\text { (N) }\end{array}$ & Resilience & $\begin{array}{c}\text { Adhesivene } \\
\text { ss }\end{array}$ \\
\hline \multirow{9}{*}{$\mathrm{NaCl}$} & & $0.50 \%$ & $\begin{array}{l}0.63 \pm \\
0.02^{\mathrm{de}}\end{array}$ & $\begin{array}{l}86.90 \pm \\
2.29^{\text {cdef }}\end{array}$ & $0.25 \pm 0.33^{c}$ & $\begin{array}{l}0.12 \pm \\
0.72^{d}\end{array}$ & $\begin{array}{c}-1.41 \pm \\
2.17^{\mathrm{a}}\end{array}$ \\
\hline & & $0.75 \%$ & $\begin{array}{l}0.69 \pm \\
0.02^{\text {cd }}\end{array}$ & $\begin{array}{l}90.35 \pm \\
2.29^{\text {bcd }}\end{array}$ & $0.26 \pm 0.33^{c}$ & $\begin{array}{l}0.12 \pm \\
0.72^{d}\end{array}$ & $\begin{array}{c}-0.69 \pm \\
2.17^{\mathrm{a}}\end{array}$ \\
\hline & & $1.00 \%$ & $\begin{array}{l}0.69 \pm \\
0.02^{\text {cd }}\end{array}$ & $\begin{array}{c}82.92 \pm \\
2.29^{f} \\
\end{array}$ & $0.26 \pm 0.33^{c}$ & $\begin{array}{l}0.11 \pm \\
0.72^{\mathrm{d}}\end{array}$ & $\begin{array}{c}-0.50 \pm \\
2.17^{\mathrm{a}}\end{array}$ \\
\hline & & $0.50 \%$ & $\begin{array}{l}0.70 \pm \\
0.02^{c}\end{array}$ & $\begin{array}{l}91.35 \pm \\
2.29^{\mathrm{abcd}}\end{array}$ & $0.33 \pm 0.33^{c}$ & $\begin{array}{l}2.88 \pm \\
0.72^{c}\end{array}$ & $\begin{array}{l}-5.65 \pm \\
2.17^{\mathrm{ab}}\end{array}$ \\
\hline & & $0.75 \%$ & $\begin{array}{l}0.71 \pm \\
0.02^{c}\end{array}$ & $\begin{array}{l}93.06 \pm \\
2.29^{\mathrm{abc}}\end{array}$ & $0.26 \pm 0.33^{c}$ & $\begin{array}{l}5.35 \pm \\
0.72^{\mathrm{ab}}\end{array}$ & $\begin{array}{l}-9.05 \pm \\
2.17^{b}\end{array}$ \\
\hline & & $1.00 \%$ & $\begin{array}{c}0.71 \pm \\
0.02^{\mathrm{c}} \\
\end{array}$ & $\begin{array}{l}92.63 \pm \\
2.29^{\mathrm{abc}} \\
\end{array}$ & $0.33 \pm 0.33^{c}$ & $\begin{array}{l}3.21 \pm \\
0.72^{c} \\
\end{array}$ & $\begin{array}{l}-6.33 \pm \\
2.17^{\mathrm{ab}} \\
\end{array}$ \\
\hline & & $0.50 \%$ & $\begin{array}{l}0.85 \pm \\
0.02^{b}\end{array}$ & $\begin{array}{c}95.86 \pm \\
2.29^{\mathrm{ab}}\end{array}$ & $7.12 \pm 0.33^{\mathrm{a}}$ & $\begin{array}{l}5.45 \pm \\
0.72^{\mathrm{ab}}\end{array}$ & $\begin{array}{c}-45.37 \pm \\
2.17^{\mathrm{de}}\end{array}$ \\
\hline & & $0.75 \%$ & $\begin{array}{l}0.89 \pm \\
0.02^{\mathrm{ab}}\end{array}$ & $\begin{array}{c}97.02 \pm \\
2.29^{\mathrm{a}}\end{array}$ & $6.00 \pm 0.33^{b}$ & $\begin{array}{l}4.52 \pm \\
0.72^{\mathrm{bc}}\end{array}$ & $\begin{array}{c}-39.46 \pm \\
2.17^{\text {cd }}\end{array}$ \\
\hline & & $1.00 \%$ & $\begin{array}{l}0.92 \pm \\
0.02^{\mathrm{a}}\end{array}$ & $\begin{array}{c}97.44 \pm \\
2.29^{\mathrm{a}} \\
\end{array}$ & $6.08 \pm 0.33^{b}$ & $\begin{array}{l}4.38 \pm \\
0.72^{\mathrm{bc}} \\
\end{array}$ & $\begin{array}{c}-38.70 \pm \\
2.17^{c} \\
\end{array}$ \\
\hline \multirow{6}{*}{$\mathrm{KCl}$} & & $0.50 \%$ & $\begin{array}{l}0.63 \pm \\
0.02^{\mathrm{de}}\end{array}$ & $\begin{array}{l}85.96 \pm \\
2.29^{\mathrm{def}}\end{array}$ & $0.28 \pm 0.33^{c}$ & $\begin{array}{l}0.13 \pm \\
0.72^{d}\end{array}$ & $\begin{array}{l}-3.92 \pm \\
2.17^{\mathrm{ab}}\end{array}$ \\
\hline & $45 \%$ & $1.00 \%$ & $\begin{array}{l}0.67 \pm \\
0.02^{\text {cde }}\end{array}$ & $\begin{array}{l}83.52 \pm \\
2.29^{\mathrm{ef}}\end{array}$ & $0.21 \pm 0.33^{c}$ & $\begin{array}{l}0.11 \pm \\
0.72^{d}\end{array}$ & $\begin{array}{c}-0.79 \pm \\
2.17^{\mathrm{a}}\end{array}$ \\
\hline & & $1.50 \%$ & $\begin{array}{c}0.71 \pm \\
0.02^{c} \\
\end{array}$ & $\begin{array}{l}86.30 \pm \\
2.29^{\mathrm{def}} \\
\end{array}$ & $0.28 \pm 0.33^{c}$ & $\begin{array}{l}0.09 \pm \\
0.72^{d}\end{array}$ & $\begin{array}{c}-0.75 \pm \\
2.17^{\mathrm{a}} \\
\end{array}$ \\
\hline & \multirow{3}{*}{$55 \%$} & $0.50 \%$ & $\begin{array}{l}0.61 \pm \\
0.02^{\mathrm{e}}\end{array}$ & $\begin{array}{l}88.01 \pm \\
2.29^{\text {cdef }}\end{array}$ & $0.26 \pm 0.33^{c}$ & $\begin{array}{l}7.37 \pm \\
0.72^{a}\end{array}$ & $\begin{array}{c}-7.65 \pm \\
2.17^{b}\end{array}$ \\
\hline & & $1.00 \%$ & $\begin{array}{c}0.71 \pm \\
0.02^{c}\end{array}$ & $\begin{array}{l}92.14 \pm \\
2.29^{\text {abcd }}\end{array}$ & $0.28 \pm 0.33^{c}$ & $\begin{array}{l}3.28 \pm \\
0.72^{c}\end{array}$ & $\begin{array}{l}-6.03 \pm \\
2.17^{\mathrm{ab}}\end{array}$ \\
\hline & & $1.50 \%$ & $0.73 \pm$ & $89.23 \pm$ & $0.22 \pm 0.33^{c}$ & $0.13 \pm$ & $-3.46 \pm$ \\
\hline
\end{tabular}

This article is protected by copyright. All rights reserved. 


\begin{tabular}{|c|c|c|c|c|c|}
\hline & $0.02^{c}$ & $2.29^{\text {cde }}$ & & $0.72^{d}$ & $2.17^{\mathrm{ab}}$ \\
\hline $0.50 \%$ & $\begin{array}{l}0.88 \pm \\
0.02^{\mathrm{ab}}\end{array}$ & $\begin{array}{c}96.58 \pm \\
2.29^{\mathrm{ab}}\end{array}$ & $6.14 \pm 0.33^{b}$ & $\begin{array}{l}5.69 \pm \\
0.72^{\mathrm{ab}}\end{array}$ & $\begin{array}{c}-37.46 \pm \\
2.17^{\mathrm{c}}\end{array}$ \\
\hline $1.00 \%$ & $\begin{array}{l}0.90 \pm \\
0.02^{\mathrm{ab}}\end{array}$ & $\begin{array}{c}97.07 \pm \\
2.29^{\mathrm{a}}\end{array}$ & $7.44 \pm 0.33^{\mathrm{a}}$ & $\begin{array}{l}6.02 \pm \\
0.72^{\mathrm{ab}}\end{array}$ & $\begin{array}{c}-42.74 \pm \\
2.17^{\text {cde }}\end{array}$ \\
\hline & $\begin{array}{l}0.90 \pm \\
0.02^{\mathrm{ab}}\end{array}$ & $\begin{array}{c}97.15 \pm \\
2.29^{\mathrm{a}} \\
\end{array}$ & $7.10 \pm 0.33^{\mathrm{a}}$ & $\begin{array}{l}4.58 \pm \\
0.72^{\mathrm{bc}}\end{array}$ & $\begin{array}{c}-46.36 \pm \\
2.17^{\mathrm{e}}\end{array}$ \\
\hline
\end{tabular}

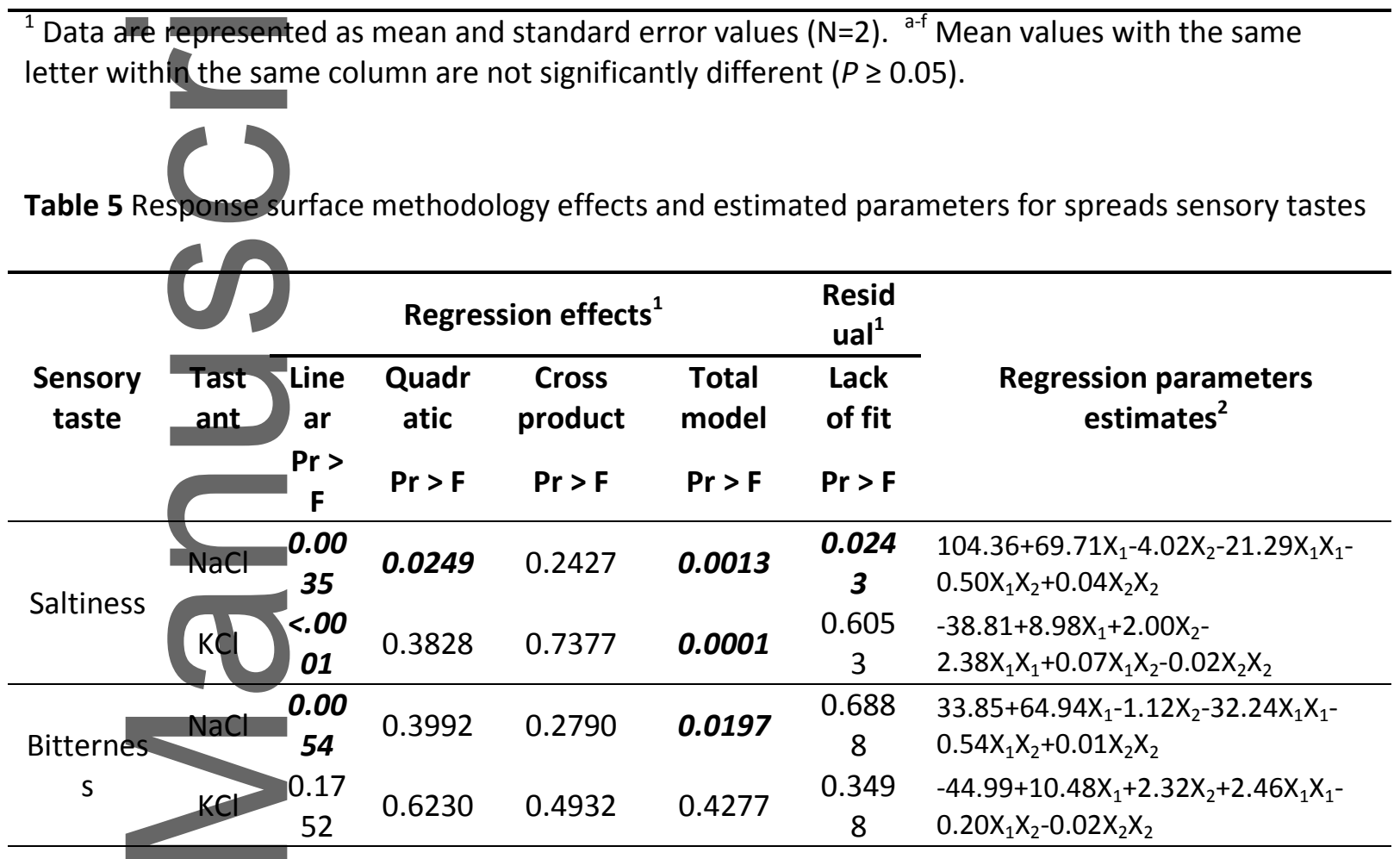

${ }^{1}$ Effects were considered significant when the probability $\mathrm{Pr}>\mathrm{F}$ was less than 0.05 (Bolded and italicized probabilities).

${ }^{2}$ For $\mathrm{NaCl}$ saltiness or bitterness, $\mathrm{X}_{1}=\%$ of $\mathrm{NaCl}$ and $\mathrm{X}_{2}=\%$ of oil; for $\mathrm{KCl}$ saltiness or bitterness, $\mathrm{X}_{1}=$ $\%$ of $\mathrm{KCl}$ and $\mathrm{X}_{2}=\%$ of oil.

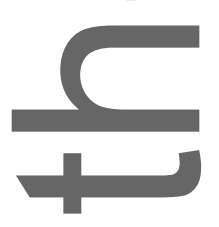

Table 6 Odds ratio estimates and probabilities* for predicting purchase intent of the spreads

\begin{tabular}{lcccc}
\hline & \multicolumn{4}{c}{ Tastant } \\
\cline { 2 - 5 } Sensory-Attributes & \multicolumn{2}{c}{$\mathrm{NaCl}$} & \multicolumn{3}{c}{$\mathrm{KCl}$} \\
\cline { 2 - 5 } & Estimate & $\operatorname{Pr}>\chi^{2 *}$ & Estimate & $\operatorname{Pr}>\chi^{2}$ \\
\hline Tastant concentration & 1.232 & 0.7680 & 1.084 & 0.8309 \\
Oil concentration & $\mathbf{1 . 0 4 7}$ & $\mathbf{0 . 0 1 3 8}$ & 0.997 & 0.8891 \\
Saltiness intensity & 1.006 & 0.6127 & 1.002 & 0.8531
\end{tabular}

This article is protected by copyright. All rights reserved. 


\begin{tabular}{lllll} 
Bitterness intensity & 0.995 & 0.6781 & 1.016 & 0.1276 \\
Overall taste liking & $\mathbf{3 . 5 5 4}$ & $<.0001$ & $\mathbf{3 . 8 2 9}$ & $<.0001$ \\
\hline
\end{tabular}

Figure 1 Response contours for saltiness and bitterness intensities ${ }^{1}$ with design points and surface plots for $\mathrm{NaCl}$ and $\mathrm{KCl}$ mayonnaise-type spreads
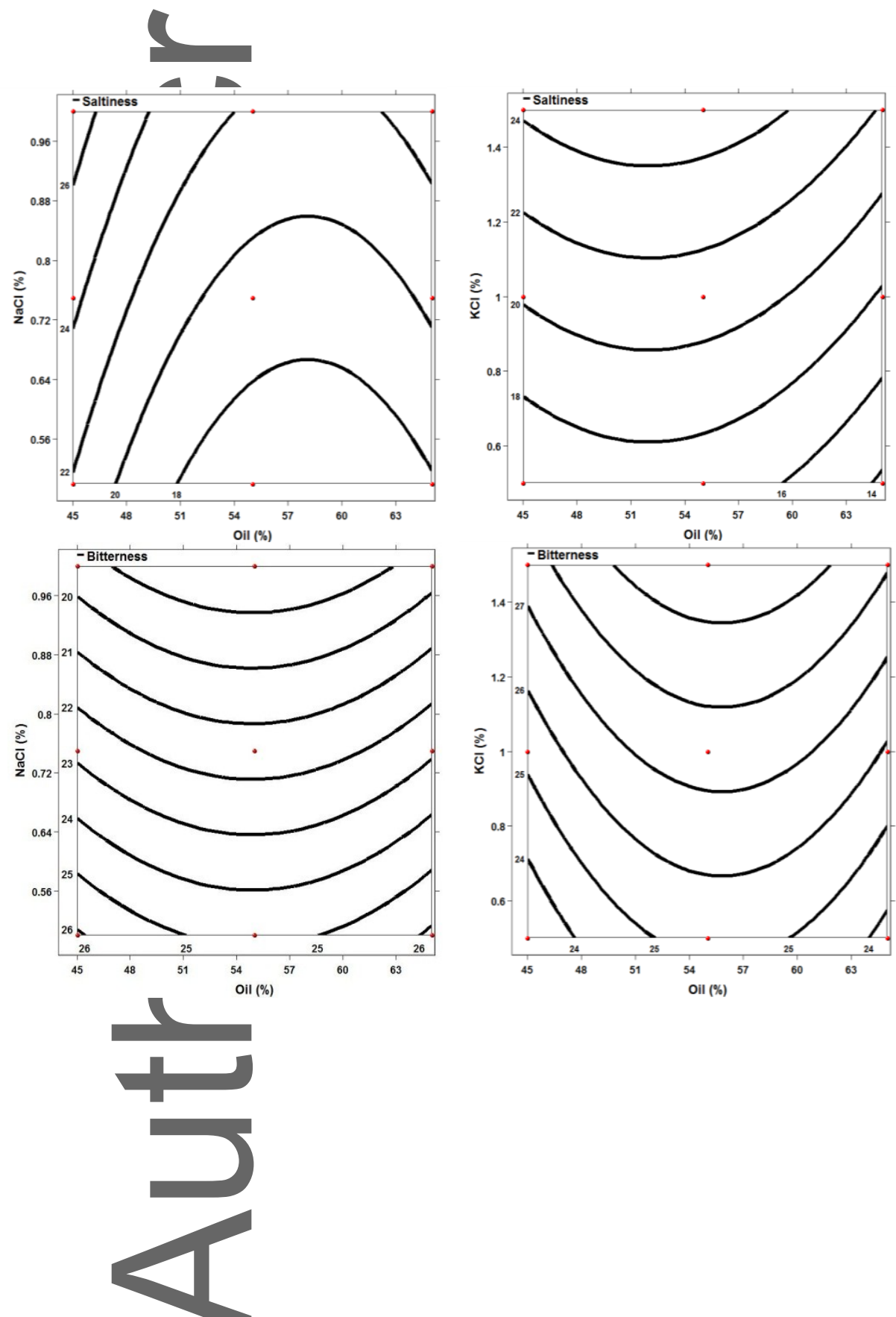

${ }^{1}$ A total of 306 consumer panelists participated in the sensory evaluation generating $\mathrm{N}=51$ repetitions per design data point. See Table 2 footnote for $\%$ oil, $\% \mathrm{NaCl}$ and $\% \mathrm{KCl}$ in oil-in-water emulsions. 
Figure 2 Total penalty scores in overall taste liking of $\mathrm{NaCl}$ and $\mathrm{KCl}$ emulsions (spreads) for viscosity, saltiness and bitterness
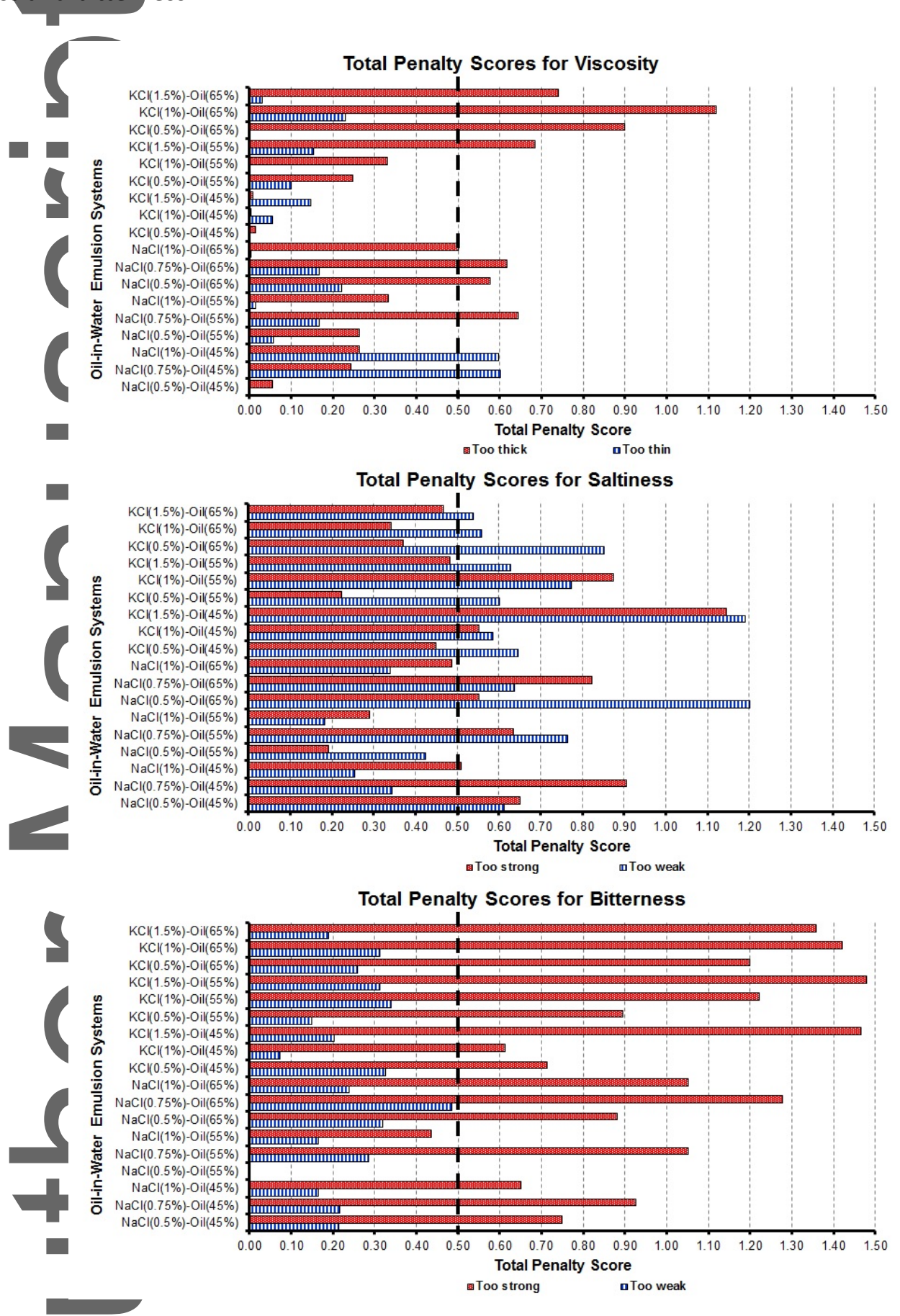

* Based on the logistic regression analysis (LRA), using a full model with 2 product-composition parameters (tastant and oil percentages) and 3 sensory attributes (saltiness, bitterness and overall taste liking). The analysis of maximum likelihood estimates was used to obtain the parameter estimates. Odds ratios represent the positive or neutral over negative purchase intent responses.

** Parameter estimates were considered significant when the probability of the Wald $\chi^{2}$ was $<0.05$.

This article is protected by copyright. All rights reserved. 
Figure 3 Dendrogram from cluster analysis of different emulsion systems ( $\mathrm{NaCl}$ and $\mathrm{KCl}$ ) considering sensory, physical and textural attributes.

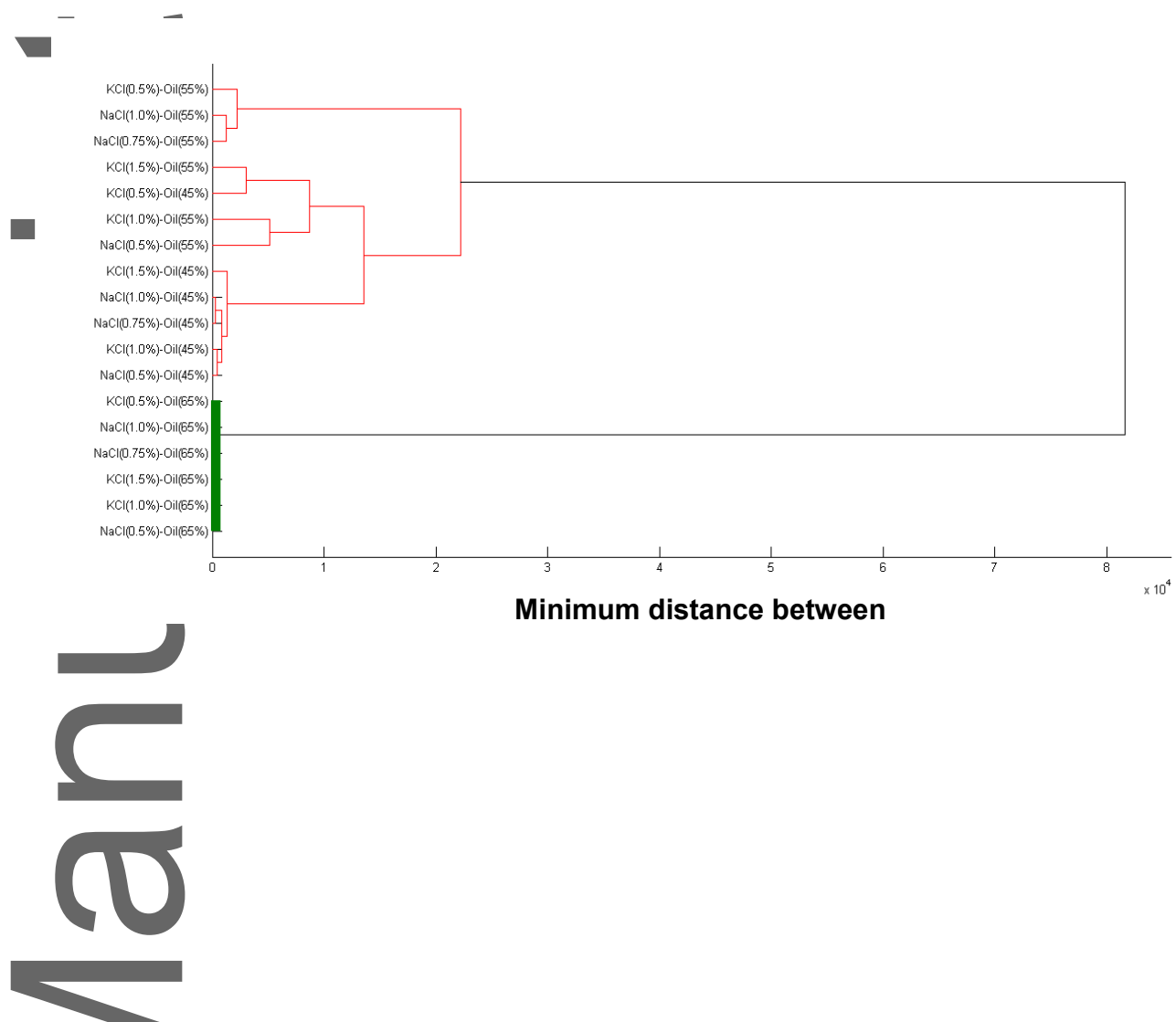

Figure 4 Principal component analysis (PCA) product-attribute bi-plot: A score plot of the first principal component (PC1) and second principal component (PC2) visualizing treatments $(\mathrm{NaCl}$ and $\mathrm{KCl}$ emulsion systems) and sensory, physical and textural attributes. Dashed line vectors represent sensory attributes and solid line vectors represent physical and textural attributes

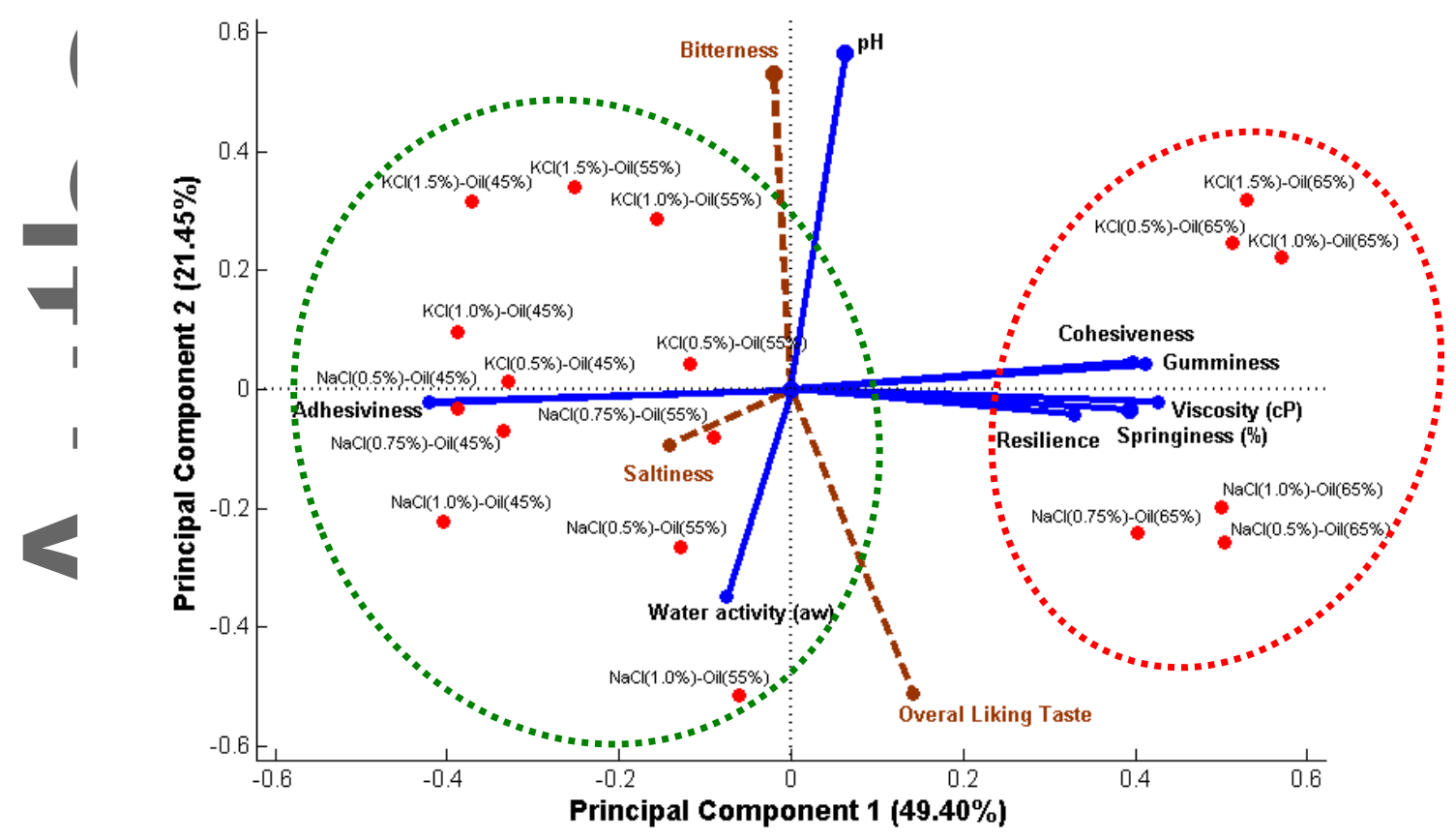

This article is protected by copyright. All rights reserved. 


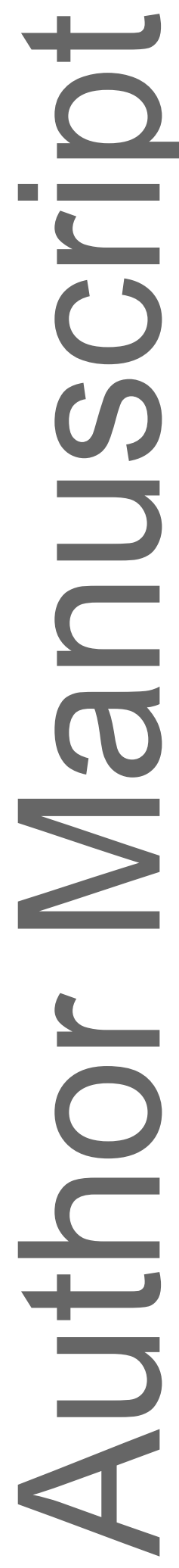

This article is protected by copyright. All rights reserved. 


\section{University Library}

\section{- $\mathrm{M}$ IIN E R VA A gateway to Melbourne's research publications}

Minerva Access is the Institutional Repository of The University of Melbourne

Author/s:

Torrico, DD;Prinyawiwatkul, W

Title:

Increasing Oil Concentration Affects Consumer Perception and Physical Properties of Mayonnaise-type Spreads Containing KCl

Date:

2017-08-01

\section{Citation:}

Torrico, D. D. \& Prinyawiwatkul, W. (2017). Increasing Oil Concentration Affects Consumer Perception and Physical Properties of Mayonnaise-type Spreads Containing KCl. JOURNAL OF FOOD SCIENCE, 82 (8), pp.1924-1934. https://doi.org/10.1111/1750-3841.13781.

Persistent Link:

http://hdl.handle.net/11343/293086 